\title{
Possible Protective Role of Citrate Against Apoptosis and Disruption of Intercalated Disc Integrity in a Rat Model of Diabetic Cardiomyopathy
}

\author{
HANAN N. GADALLAH, M.D.; MOHAMED E. ELDIN IBRAHI, M.D.; \\ BASMA EMAD MOHAMED SAAD, M.Sc. and REDA ABDEL NASSER IMAM, M.D.
}

The Department of Anatomy and Embryology, Faculty of Medicine, Cairo University

\begin{abstract}
Background: Cardiac apoptosis and disruption of intercalated disc integrity had been described as adverse changes complicating diabetes.

Aim of Study: To investigate possible prophylactic role of citrate against these adverse cardiac changes.

Material an Methods: Twenty four rats were utilized in this research, randomly divided into 4 groups (6 for each): Control group (I), citrate alone received group (II) $(5 \mu \mathrm{g} / \mathrm{kg}$ sodium citrate every other day IP), Streptozocin-induced diabetic group (III) (Strepyozocin single IP injection of 50 $\mathrm{mg} / \mathrm{kg}$ ), citrate prophylactic (citrate injections after induction of diabetes) group (IV). All rats were euthanized 8 weeks from the onset of the experiment. The heart with all its chambers were obtained, cardiac malondialdehyde (MDA) and glutathione (GSH) were measured, heart sections were processesd for histological and immunohistochemical (caspase 3, desmin and connexin 43) analysis.
\end{abstract}

Results: Citrate had significantly $p<0.05$ modulated cardiac (MDA) and (GSH) as compared to diabetic rats. It had reduced the histological deleterious effect of diabetes on heart tissues. caspase 3 immunoreaction optical density had been significantly $p<0.05$ decreased in citrate prophylactic group as compared to diabetic group. Desmin and connexin $43 \mathrm{immu}-$ noreaction optical density had significantly increased in citrate prophylactic group as compared to diabetic group.

Conclusion: Citrate might mitigate cardiac apoptosis in diabetic rats and might maintain the integrity of intercalated discs.

Key Words: Diabetes - Heart-Citrate - Rats - Intercalated disc.

\section{Introduction}

DIABETIC cardiomyopathy is defined as myocardial dysfunction without the presence of valvular heart, hypertension or coronary artery disease [1] The pathophysiology of DCM had been proved to

Correspondence to: Dr. Reda Abdel Nasser Imam, E-Mail: abdelnasserreada@gmail.com include cardiac inflammation and liberation of large amount of reactive oxygen species [2] . Diabetic cardiomyopathy is manifested grossly by left ventricular hypertrophy and myocardial fibrosis, haemodynamically by damaged left ventricular systolic and diastolic functions [3] . Citric acid is found naturally in citrus fruits, such as orange, tangerine lemon and grapefruit. It is considered as a weak organic acid and Lemon as well as lime juice are rich sources [4]. Citric acid, a component of Krebs cycle, had been stated to be found in all animal tissues in the of oxidative metabolism [5] In vitro, through reducing the inflammatory substances and decreasing hyperglycemic neutrophil diapedesis, citrate had been suggested to improve endothelial function [6]. The ability of citrate to bind calcium and metals that produce large amounts of reactive oxygen species might suggest its chelating power [7]. Currently, there was no remarkable effect in the treatment of DCM with the application of single Western medicine [3]. In this work, we aim to investigate the prophylactic role of citrate against cardiac apoptosis and disruption of intercalated disc integrity in rats.

\section{Material and Methods}

Animals:

The study was complied to the ethics of Animal Research and was approved by the Local Ethical Committee of Faculty of Medicine, Cairo University. This study was carried out at 2018 on 24 male albino rats weighing 150-200g obtained from the Animal House, Faculty of Medicine, Cairo University. The animals were left 2 weeks berfore the experiment for acclimatization. The rats were housed under standard laboratory conditions with free access to standard pellet chow and drinking 
water. Biochemical and blood analysis was carried out at the Biochemistry Department, Faculty of Medicine, Cairo University.

\section{Chemicals:}

Streptozotocin (Sigma-Aldrich, St. Louis, MO, USA), Citrate (sodium citrate, EIPICO, Egypt), MDA and GSH (MyBiosource, USA), Caspase 3 (Santa Cruz, USA), Desmin (ThermoFisher, USA), Connexin43 (Dako, Denmark).

1- Streptozotocin (STZ): STZ powder was dissolved in citrate buffer ( $\mathrm{pH} 4.5)$, given intraperitoneally in a single dosage of $50 \mathrm{mg} / \mathrm{kg}$ bw, in a vehicle of $0.5 \mathrm{ml}$ citrate buffer to induce diabetes [8].

2- Sodium citrate: Its powder was dissolved in sterile water and given every day other by intraperitoneal injection in a dosage of $5 \mathbf{g} / \mathbf{k}$ bw in a vehicle of $0.5 \mathrm{ml}$ sterile water per dose [9]

\section{Procedure and induction of diabetes:}

- Twelve rats were subjected to induction of diabetes as follows:

1- Following overnight fasting, a single dose of STZ was intraperitoneally injected.

2- Three days later a blood samples were taken from the tail vein and glucose levels were measured to confirm diabetes.

3- Diabetic rats whose blood glucose level was $250 \mathrm{mg} / \mathrm{dl}$ or higher were used.

4- The established point of diabetes was considered as the onset of the experiment.

\section{Experimental design:}

Twenty four rats were categorized into four groups (6 rats for each group): Control group (I): Received no medication, citate alone group (II): Received citrate alone, (diabetic group III) and citrate prophylactic group (IV): Received sodium citrate after induction of diabetes starting from the onset of the experiment, all medications were given at fixed time per day.

Determination of blood glucose level and body weight:

- At the designated end of the study, blood samples were collected from the tail vein and used for determination of blood glucose level.

- Then the total Body Weight (BW) of the rat was recorded [10]

\section{Euthanasia and dissection:}

- All rats were sacrificed by cervical dislocation 8 weeks from the onset of experiment [9].
- The rats were dissected and the heart of each animal was immediately excised and processed for biochemical, histological and histochemical analysis [11].

\section{Biochemical analysis:}

- Parts of the hearts obtained from each animal were incubated in 0.1M Phosphate Buffer Saline (PBS) solution and centrifuged at $1200 \mathrm{~g}$ for 10 minutes the the resulting supernatant was used to determine the (MDA) and (GSH) levels [12]

\section{Histological study:}

Other parts of the heart from each rat were fixed immediately in $10 \%$ formol saline, sections of 5 thickness were subjected to Haematoxylin and eosin (H \& E) staining [13].

\section{Immunohistochemical study:}

Deparaffinized sections on were put on positively charged slides that used for detection of caspase 3 (to evaluate apoptosis) and connexin 43 as well as desmin (to assess the integrity of intercalated disc). Immunohistochemical reaction was evaluated using various primary antibodies caspase 3 (Rabbit polyclonal, 1;100), desmin (Rabbit polyclonal, 1;100) and connexin 43 (Rabbit polyclonal, $1 ; 100)$. HRP system was used for labeling with 2ry antibodies [14,15]

\section{Histomorphometric analysis:}

"Leica Qwin 500C" software was used to measure the optical density of immunoreaction of caspase 3, desmin and connexin 43 in magnifications of 400 .

\section{Statistical analysis:}

All variables were statistically analyzed using Microsoft Excel worksheet, 2016 with ANOVA followed by post hoc Tukey test for data analysis which was expressed as means \pm Standard Deviation (SD). Significance was considered according to post hoc Tukey test results.

\section{Results}

Body weight:

Diabetic group BW was significantly decreased compared to control group. It was significantly increased in citrate prophylactic group compared to diabetic group (Table 1).

\section{Biochemical results:}

The blood glucose level of diabetic group was significantly increased as compared to control group. It was significantly decreased in prophylactic 
group compared to diabetic group (Table 1). GSH of diabetic group was significantly decreased as compared to control group (Table 2). It was significantly increased in prophylactic group compared to diabetic group (Table 2). The MDA level of diabetic group was significantly increased as compared to control group. It was significantly decreased in prophylactic group compared to diabetic group (Table 2).

\section{Histological results:}

By $\mathrm{H} \&$ E staining Fig. (1), control and citrate alone groups showed regular branching cardiomyocytes with vesicular nuclei and intercalated disc inbetween. Diabetic group exhibited swollen cardiomyocytes, widening of interstitial spaces, cellular inflammatory infiltrate, interstitial hemorrhage and apoptotic cardiomyocytes with eosinophilic cytoplasm and dark nuclei. Citrate prophylactic group exhibited largely preserved cardiac cells with few cellular infiltrate and mild interstitial hemorrhage.

By Caspase 3 immunostaining Fig. (2), the control and citrate alone groups showed similar findings exhibiting negative reaction while diabetic
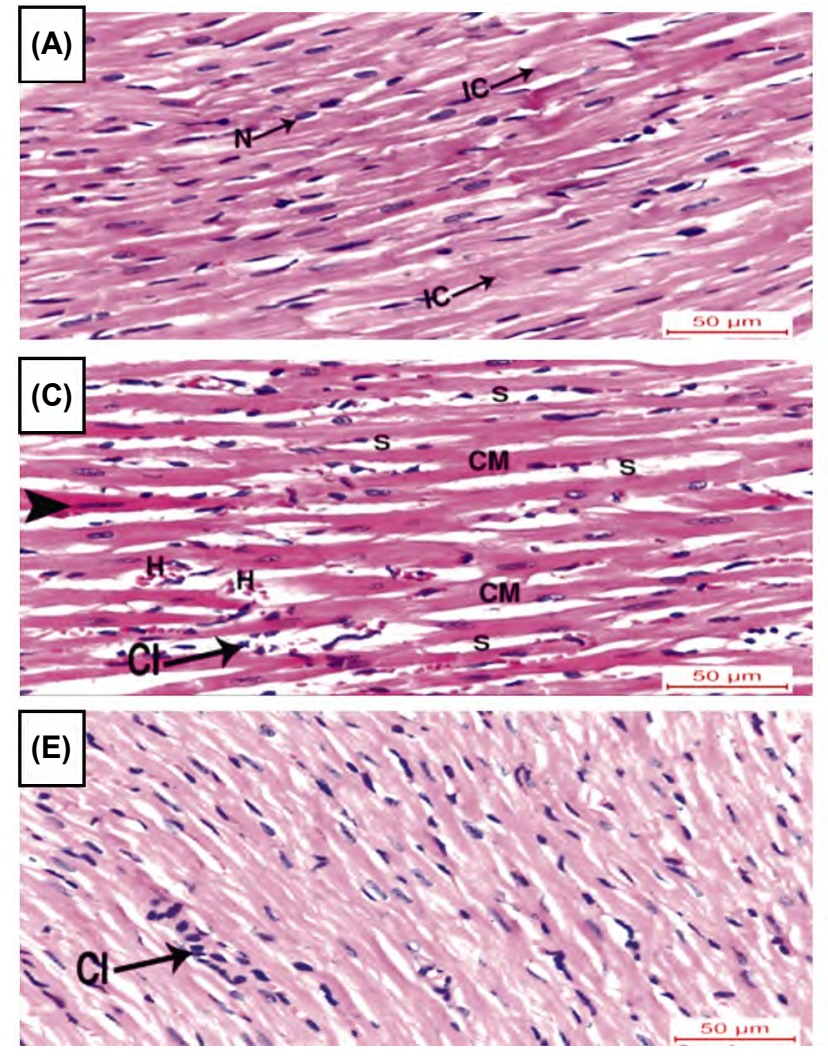

group exhibited strong reaction. Citrate prophylactic group showed decreased caspase 3 reaction.

By connexin 43 immunostaining Fig. (3), control and citrate alone showed similar findings exhibiting strong positive reaction while diabetic group exhibited markedly decreased reaction. Citrate prophylactic group exhibited largely preserved reaction.

By desmin immunostaining Fig. (4), control and citrate alone groups showed similar findings exhibiting strong positive desmin reaction while diabetic group showed marked to moderate decrease in desmin reaction. Citrate prophylactic group exhibited largely preserved reaction.

\section{Histomorphometric results Fig. (5):}

Optical density of capase 3 immunoreaction of diabetic group was significantly increased compared to control and citrate alone groups. It was significantly decreased in citrate prophylactic compared to the diabetic group. Optical density of connexin43 and desmin immunoreaction in intercalated discs of diabetic group was significantly decreased compared to control and citrate alone groups. It was significantly increased in citrate prophylactic compared to the diabetic group.
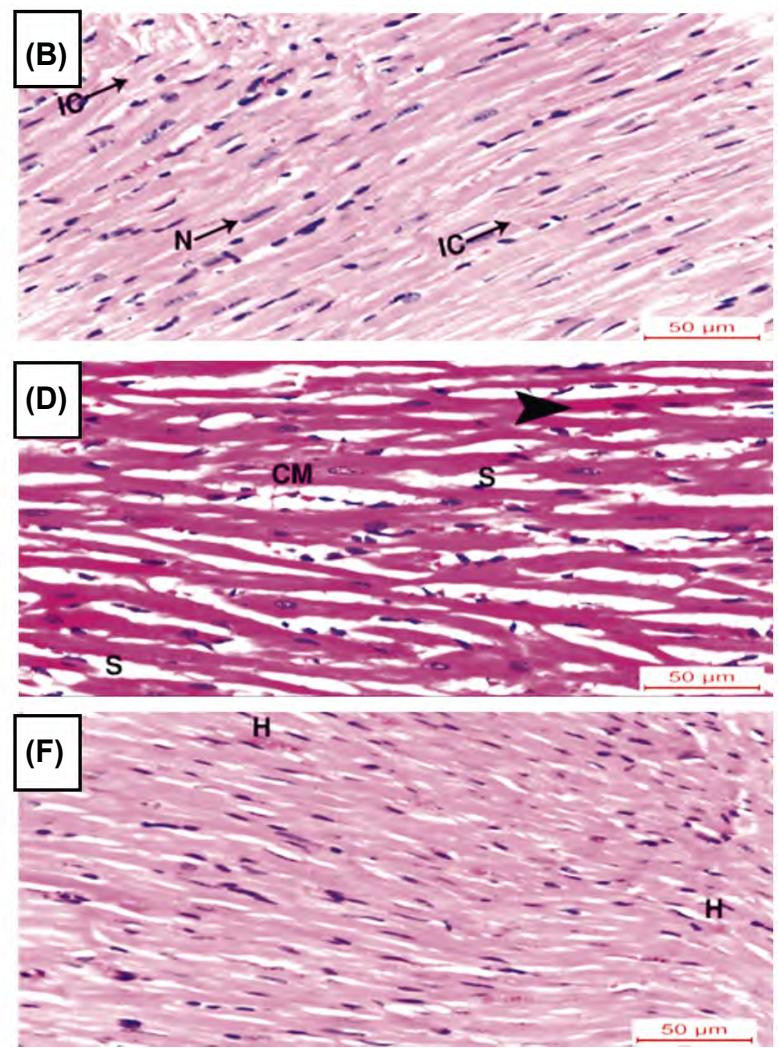

Fig. (1): (A \& B) Control and citrate alone groups are showing regular branching cardiomyocytes with vesicular nuclei (N) and Intercalated Disc (IC) inbetween. (C \& D) Diabetic group is showing swollen Cardiomyocytes (CM), widening of interstitial spaces (S), cellular inflammatory infiltrate (CI), interstitial hemorrhage $(\mathrm{H})$ and apoptotic cardiomyocytes (arrow heads) with eosinophilic cytoplasm and dark nuclei. (E \& F) Citrate prophylactic group is showing largely preserved cardiac cells with few Cellular Infiltrate (CI) and mild interstitial hemorrhage (H). (H \& E X400). 

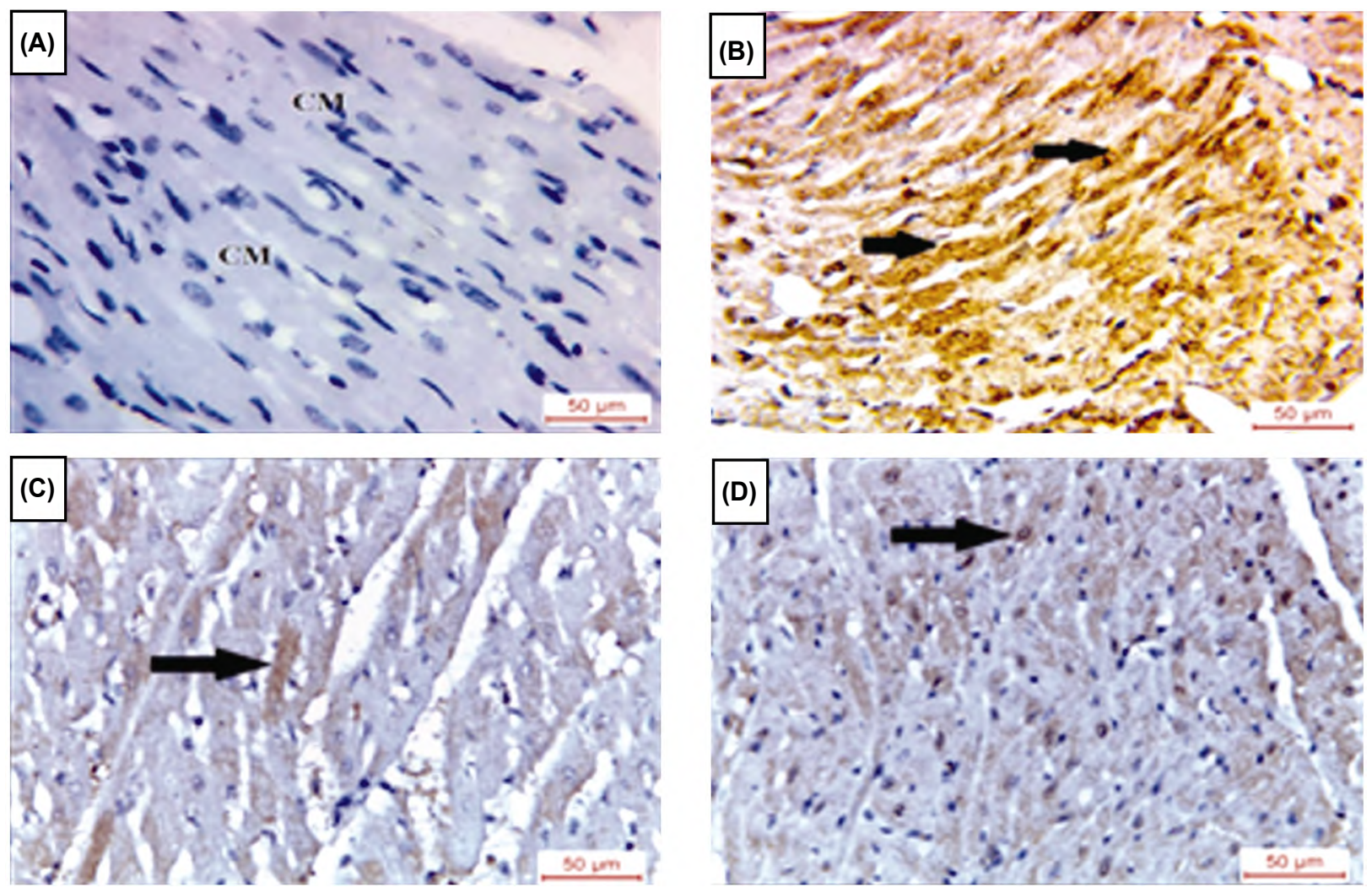

Fig. (2): (A) Control group is showing negative caspase3 reaction in cardiomyocytes (CM). (B \& C) Diabetic group is showing strong reaction (arrows). (D) Citrate prophylactic group is showing decreased caspase 3 reaction. (Caspase 3 X400).
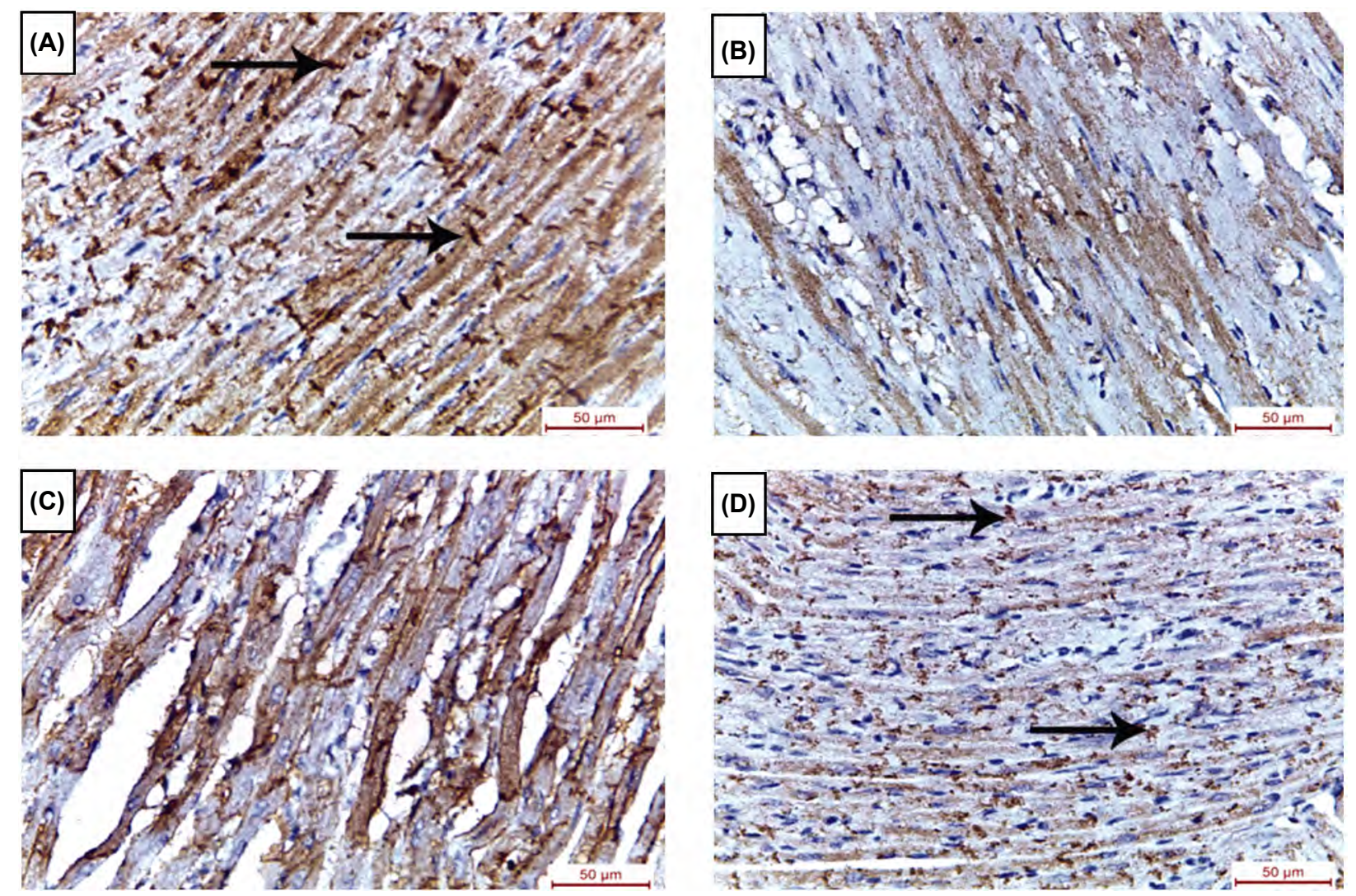

Fig. (3): (A) Control group is showing strong positive connexin43 reaction in intercalated discs (arrow). (B \& C) Diabetic group is showing markedly decreased reaction. (D) Citrate prophylactic group is showing largely preserved reaction. (Connexin43 X400). 

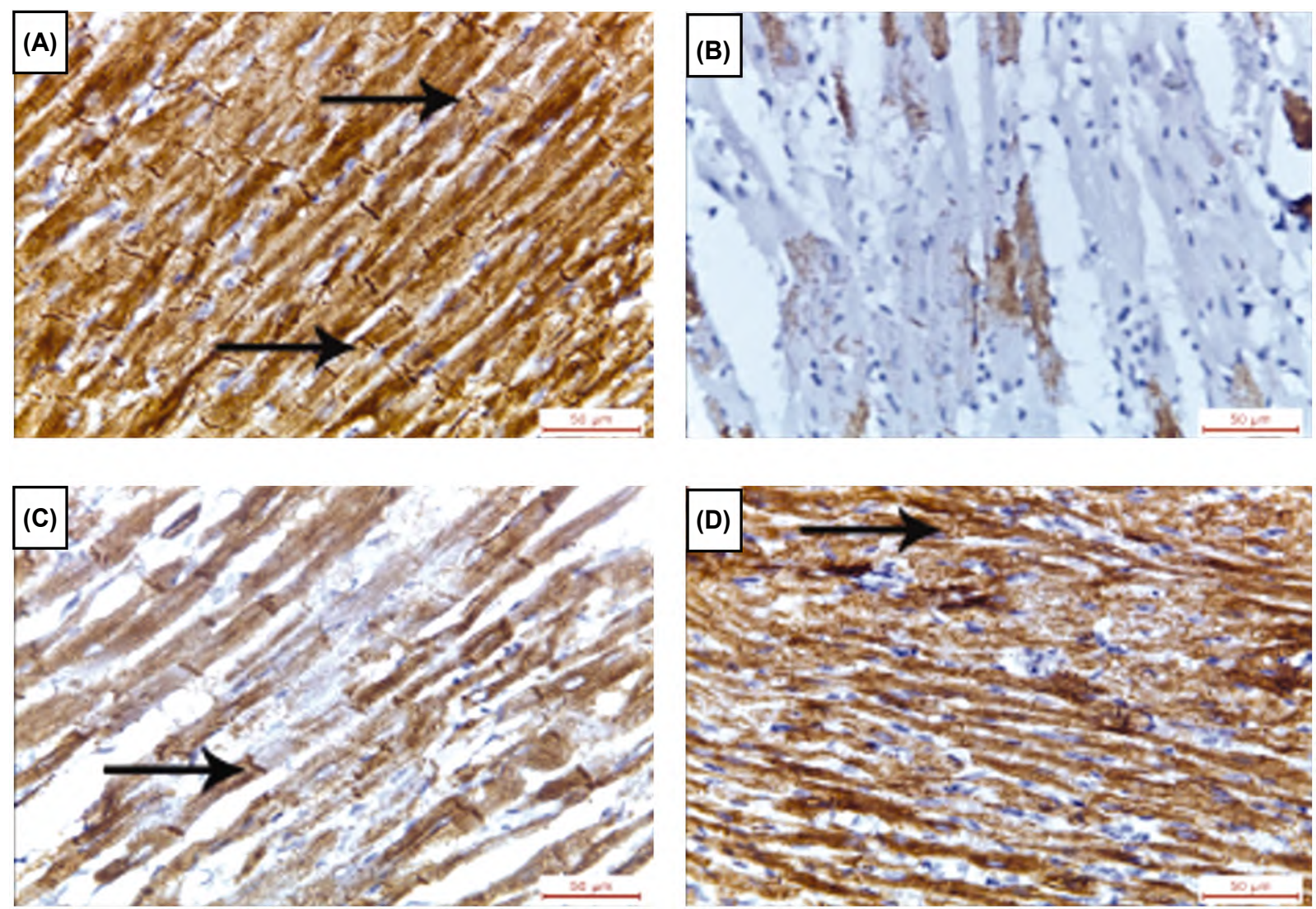

Fig. (4): Control group is showing strong positive desmin reaction (arrow). (B \& C) Diabetic Group is showing marked to moderate decrease in desmin reaction respectively. (D) Citrate prophylactic group is showing largely preserved reaction. (Desmin X400).
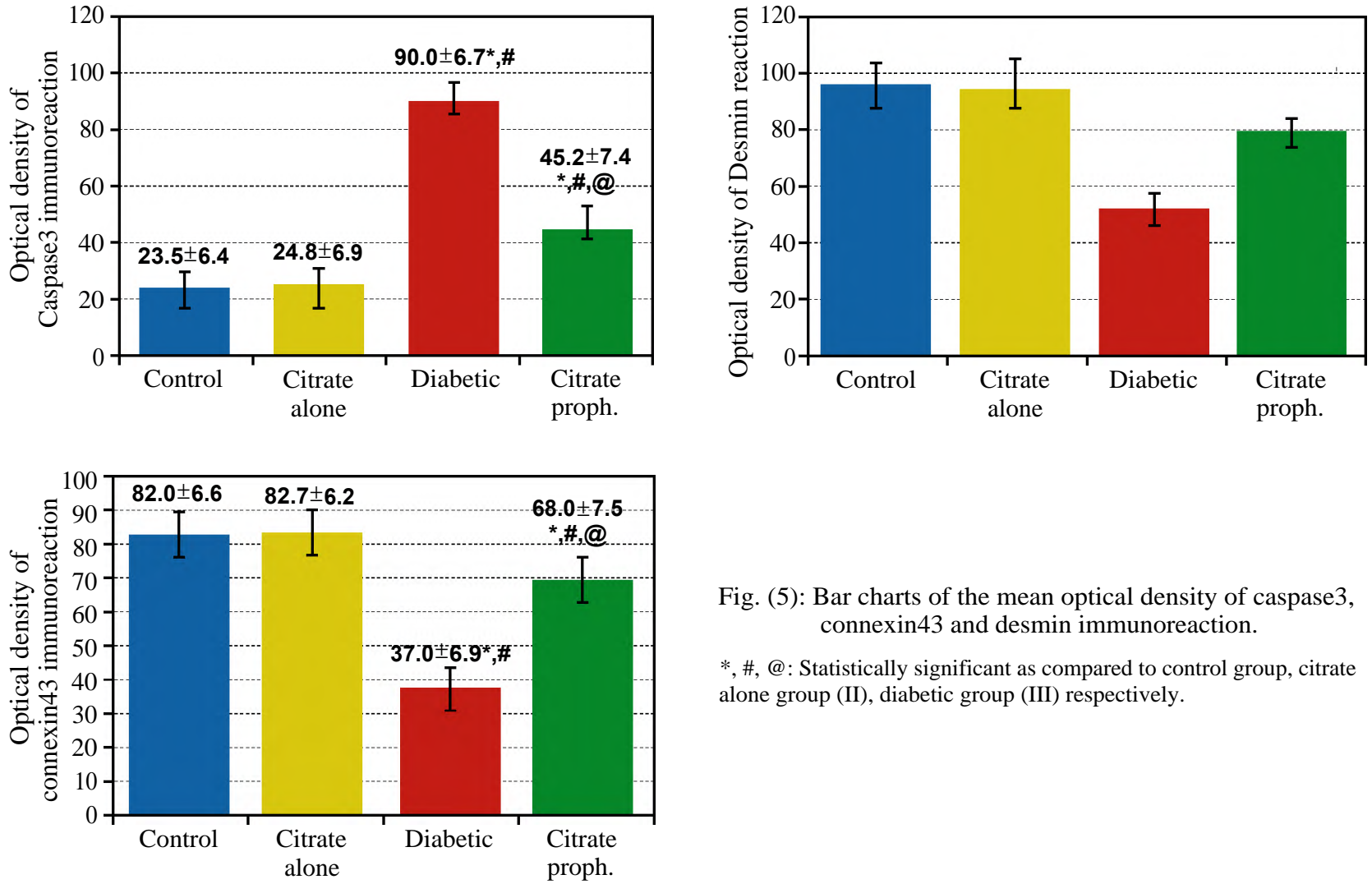

Fig. (5): Bar charts of the mean optical density of caspase3, connexin43 and desmin immunoreaction.

*,\#, @: Statistically significant as compared to control group, citrate alone group (II), diabetic group (III) respectively. 
Table (1): Mean blood glucose level and mean body weight in all groups.

\begin{tabular}{lcc}
\hline Group & $\begin{array}{c}\text { Blood glucose } \\
\text { level } \\
\text { Mean } \pm \mathrm{SD}(\mathrm{mg} / \mathrm{dl})\end{array}$ & $\begin{array}{c}\text { Body weight } \\
\text { Mean } \pm \mathrm{SD} \\
(\mathrm{g})\end{array}$ \\
\hline I (control) & $113.8 \pm 13.7$ & $166.4 .5 \pm 13.6$ \\
II (citrate alone) & $108 \pm 12.09$ & $168.3 \pm 14.9$ \\
III (diabetic) & $390.8 \pm 10.06$ & $136.4 \pm 9.9 *, \#$ \\
IV (citrate prophylactic) & $293.6 \pm 13.37$ & $168.4 \pm 15.2 @$ \\
*,\#, @: Statistically significant as compared to control group, citrate \\
\multicolumn{2}{c}{ alone group (II), diabetic group (III) respectively. }
\end{tabular}

\section{Discussion}

The present study showed that administration of citrate had ameliorated diabetic adverse cardiac changes. It had significantly decreased the mean blood glucose level compared to that of diabetic rats (groups III). Combined antioxidants application had been demonstrated to decrease blood glucose levels owing to their ability to minimize oxidative stress, protecting $\beta$-cells of the pancreas from damage [16]. In contrast, Nagai et al., [17] claimed that although citrate had ameliorated ketosis and protected against the development of diabetic, it did not affect blood glucose level in streptozotocininduced diabetic rats. This contradiction may be due to the dose and route of citric acid administration which were $2 \mathrm{~g} / \mathrm{L}$ in drinking water.

The significant decline of GSH and the rise of MDA level in the myocardium of diabetic rats (group III) compared to non-diabetic control rats in this study was in agreement with Yu et al., [18], Aouacheri et al., [19] and Hegab [20]. In addition, elevated blood glucose levels might have been proved to exacerbate mitochondrial production of reactive oxygen species and glucose oxidation $[12,21]$. However, no significant change in cardiac GSH level in diabetic rats as compared to the control group had been found [22]. Perhaps the latter findings might be attributed to the low dose of STZ they had used in their work which was $35 \mathrm{mg} / \mathrm{kg}$ bw. The significant increase of the GSH and significant decrease of the MDA in heart of rats that received citrate (group IV) compared to diabetic rats (group III) might prove the antioxidant properties of citric acid. GSH had been considered as one of the lines of cellular defense against oxidative stress [23,24]. Citric acid, by its antioxidant actions, had been hypothesized to mitigate the malathion-induced neurotoxicity [25]. The ability of citric acid to scavenger free radical species and its chelating capacities might block hyperglycemiainduced ROS production [26,27]
Table (2): Mean GSH and mean MDA levels in all groups.

\begin{tabular}{lcl}
\hline Group & $\begin{array}{c}\text { Glutathione level } \\
\text { Mean } \pm \text { SD } \\
\text { (mmol/g tissue) }\end{array}$ & $\begin{array}{c}\text { MDA level } \\
\text { Mean } \pm \text { SD } \\
\text { (mmol/g tissue) }\end{array}$ \\
\hline I (control) & $53.6 \pm 5.9$ & $8.1 \pm 2.6$ \\
II (citrate alone) & $54.9 \pm 7.2$ & $7.2 \pm 2.4$ \\
III (diabetic) & $24.3 \pm 5.6^{*}, \#$ & $47.8 \pm 7.8^{*}, \#$ \\
IV (citrate prophylactic) & $37 \pm 4.9^{*}, \#$, @ & $20.3 \pm 4.8^{*}, \#$, @ \\
\hline *, \#, @: Statistically significant as compared to control group, citrate \\
\multicolumn{2}{r}{ alone group (II), diabetic group (III) respectively. }
\end{tabular}

Histologically, in the current experiment, diabetic rats (group III) revealed apoptosis, widening of interstitial spaces and cellular inflammatory infiltrate. These results were in agreement with the previous study carried out by Zhang et al., [28] who explained the widespread myocardial structure disorder and necrotic myocardial muscle fibers in diabetic rats to impairment of membrane structure and functional integrity in cardiomyocytes of diabetic rats. In addition, Guo et al., [29] explained the necrotic cardiomyocytes and infiltration of inflammatory cells in diabetic rats, by the significant rise in pro-hypertrophic proteins such as ANP, $\mathrm{BNP}$, and $\beta-\mathrm{MyHC}$ mRNA expression due to hyperglycemia. Furthermore, Othman et al., [30] attributed the inflammatory cell infiltration in diabetic rat myocardium to the elevation in serum levels of TNF-a, IL- $1 \beta$ and IL-6, ICAM- 1 and VCAM-1, which are pro-inflammatory cytokines, up-regulating adhesion molecules and augmenting inflammatory responses and adhesion of leukocytes on the endothelial cell surface. Interstitial hemorrhage which was observed in diabetic rats (group III) in the present study might be due to congestion of the blood vessels with thickened endothelial cell swelling due to oxidative stress [31]. In the current work, treatment of diabetic animals with citrate (group IV) had ameliorated the histological destruction caused by diabetes. Supporting our results, Liang et al., [9] detected that intraperitoneal citrate injection had improved deleterious diabetic cardiac changes represented by decreased cell death, fibrosis, inflammatory and apoptotic responses as well as collagen accumulation. The antiinflammatory, anti-platelet aggregation and direct cardiac protective effects of the citric acid have been proposed as underlying mechanisms for its protective effects [32]

Myocardial cell death as detected in caspase3 stained sections of diabetic rats (group III) augment the work carried out by Tian et al., [33] and $\mathrm{Yu}$ et al., [31] who detected a significant rise in the 
percentage of apoptotic myocardial cells in the diabetic mice. Citrate had significantly reduced the optical density of Caspase 3 positive reaction compared to diabetic rats in the current work. These findings supported the work done by Tang et al., [32] who suggested that citric acid might reduce Hypoxia/Reoxygenation (H/R)-induced cardiac apoptosis. In addition, citrate administration in diabetic mice had increased energy charge and inhibited cell membrane damage by inhibiting the production of ROS and mitochondrial damage that leads to reduction of the apoptotic and inflammatory changes in the hearts of diabetic mice $[\mathbf{9 , 3 4}]$.

Diabetic group (III) inn this work exhibited few connexin 43 +ve intercalated discs, confirmed by a significant decrease in the mean optical density of connexin reaction. This finding declared that diabetes had disrupted the integrity of intercellular gap junction protein present in the hexameric connexon hemi-channels at the discs. Concordantly, connexin 43 disorganization in diabetic hearts was explained by the decrease in its tyrosine phosphorylation as the diabetic disease progresses $[35,36]$ The latter authors reported that connexin 43 isomer has a rapid turnover rate compared to other cardiac proteins and might represent an early and sensitive investigation tool. In citrate prophylactic group (group IV), multiple connexin 43 +ve discs were apparent, confirmed by a significant increase in the optical density of positive connexin43 reaction compared to group III. This denoted the ability of citrate to maintain the integrity of intercalated disc proteins. The mechanism by which citrate had modulated connexin 43 immunoexpression in intercalated disc in the current research is unclear and further workups are needed.

Desmin reaction had been decreased in diabetic group in the current work, confirmed by significant decline in the optical density of positive desmin reaction as compared to control rats. Desmin was found to connect the Z-disk to the subsarcolemmal cytoskeleton and so connect the contractile apparatus to the cell nucleus, mitochondria, and postsynaptic areas of motor endplates [37,38]. Desmin also had been reported as an intermediate filament protein, tethering the Z-disks to the plasma membrane and preserving structural integrity of myofibrils in both skeletal and cardiac tissues [39]. The latter authors also reported that desmin gene mutations had been implicated in dilated cardiomyopathy. Citrate received rats in this work exhibited significant rise in desmin reaction as compared to diabetic rats. The novelty of the current work in studying the cardiac desmin immuno-reaction in diabetes and improving effect of citrate in this reaction might suggest the sarcomeres structural integrity maintaining role of citrate against adverse diabetic cardiac changes.

In conclusion, citrate could mitigate cardiac apoptosis in diabetic rats and can maintain the integrity of intercalated disc proteins and protect rats against diabetic cardiomyopathy.

\section{Conflicts of interest:}

None as announced by authors.

\section{References}

1- HUYNH K., McMULLEN J.R., JULIUS T.L., et al.: Cardiacspecific IGF-1 receptor transgenic expression protects against cardiac fibrosis and diastolic dysfunction in a mouse model of diabetic cardiomyopathy. Diabetes, 59: $1512-20,2010$

2- D'AMATI G.D. and GIORDANO C.: Cardiovascular Pathology, fourth edition, Academic Press, Elsevier, Chapter 11, Cardiomyopathies, P.P. 435-83, 2016.

3- TIAN J., ZHAO Y., YANFEI L., LIU Y., KEJI CHEN K and LYU S.: Roles and Mechanisms of Herbal Medicine for Diabetic Cardiomyopathy: Current Status and Perspective. Oxidative medicine and cellular longevity, (3): 1$15,2017$.

4- PENNISTON K.L., NAKADA S.Y., HOLMES R.P. and ASSIMOS D.G.: Quantitative Assessment of Citric Acid in Lemon Juice, Lime Juice, and Commercially-Available Fruit Juice Products. Journal Endourol, 22 (3): 567-70, 2008.

5- GABUTTI L., FERRARI N., MOMBELLI G., et al.: The favorable effect of regional citrate anticoagulation on interleukin-1beta release is dissociated from both coagulation and complement activation. J. Nephrol., 17: 819$25,2004$.

6- BRYLAND A., WIESLANDER A., CARLSSON O., HELLMARK T. and GODALY G.: Citrate treatment reduces endothelial death and inflammation under hyperglycaemic conditions. Diabetes and Vascular Disease Research, 9 (1): 42-51, 2012.

7- BAYNES J.W. and MURRAY D.B.: The metal chelators, trientine and citrate, inhibit the development of cardiac pathology in the Zucker diabetic rat. Exp. Diabetes Res. 2009: 696378. doi: 10.1155/2009/696378, 2009.

8- KANTER M., AKTAS C. and ERBOGA M.: Curcumin attenuates testicular damage, apoptotic germ cell death, and oxidative stress in streptozotocin-induced diabetic rats. Molecular Nutrition and Food Research, 57 (9): 1578-85, 2013.

9- LIANG Q., WANG B., PANG L., WANG Y., ZHENG M., et al.: Application of citrate as a tricarboxylic acid (TCA) cycle intermediate, prevents diabetic-induced heart damages in mice. Iranian Journal of Basic Medical Sciences, 19 (1): 43-8, 2016.

10- CHENG M., GAO H.Q., XU L., LI B.Y., ZHANG H., et al.: Cardioprotective effects of grape seed proanthocyanidins extracts in streptozocin induced diabetic rats. Journal of Cardiovascular Pharmacology, 50 (5): 503-9, 2007. 
11- KHANRA R., DEWANJEE S., DUA T.K., SAHU R., GANGOPADHYAY M., et al.: Abroma augusta L. (Malvaceae) leaf extract attenuates diabetes induced nephropathy and cardiomyopathy via inhibition of oxidative stress and inflammatory response. Journal of Translational Medicine, 13 (6): 1-14, 2015.

12- WANG G., LI W., LU X., ZHAO X. and XU L.: Taurine attenuates oxidative stress and alleviates cardiac failure in type I diabetic rats. Croatian Medical Journal, 54 (2): 171-9, 2013.

13- BANCROFT J.D. and LAYTON C.: Connective and mesenchymal tissues with their stains. In: Theory and Practice of Histological Techniques, 7 th edition. Suvarna S.K., Layton C. and Bancroft J.D. (Eds.). Churchill Livingstone, Edinburgh, London, Madrid, Melbourne, New York and Tokyo, pp.: 200-5, 2013.

14- KHORRAMIROUZ R., JASON L.G., NOBLE C., JANA S., MAXSON E., LERMAN A., MELISSA D. and YOUNG M.D.: A novel surgical technique for a rat subcutaneous implantation of a tissue-engineered sca-old. Acta Histochemica, 120: 282-91, 2018.

15- SANDERSON S., WILD G., CULL A.M., MARSTON J. and ZARDIN G.: Bancroft's Theory and Practice of Histological Techniques, Eighth Edition, Elsevier Limited, chapter 19 (Immunohistochemical and immunofluorescent techniques), 337-94, 2019.

16-KUMAR S., PRASAD S. and SITASAWAD S.L.: Multiple Antioxidants Improve Cardiac Complications and Inhibit Cardiac Cell Death in Streptozotocin-Induced Diabetic Rats. PLoS ONE, 2; 8 (7): e67009. doi: 10.1371/ journal.pone.0067009, 2013.

17- NAGAI R., NAGAI M., SHIMASAKI S., BAYNES J.W. and FUJIWARA Y.: Citric acid inhibits development of cataracts, proteinuria and ketosis in streptozotocin (type 1) diabetic rats. Biochemical and Biophysical Research Communications, 393 (1): 118-22, 2010.

18- YU W., WU J., CAI F., XIANG J., ZHA W., et al.: Curcumin Alleviates Diabetic Cardiomyopathy in Experimental Diabetic Rats. PLoS ONE, 7 (12): 1-11, 2012.

19- AOUACHERI O., SAKA S., KRIM M., MESSAADIA A. and MAIDI I.: The Investigation of the Oxidative Stress-Related Parameters in Type2 Diabetes Mellitus. Canadian Journal of Diabetes, 39 (1): 44-9, 2015.

20- HEGAB I.I.: Ameliorative effect of apelin on streptozotocin-induced diabetes and its associated cardiac hypertrophy. Alexandria Journal of Medicine, 54: 119-27, 2018.

21- LI Y., WEN L. and GUO X.: Cardio-Protective Role of Gingerol along with Prominent Anti-Diabetic Cardiomyopathy Action in A Streptozotocin-Induced Diabetes Mellitus Rat Model. Cell J., 19 (3): 469-75, 2017.

22- MAYYAS F., JARADAT R. and ALZOUBI K.H.: Cardiac effects of fish oil in a rat model of streptozotocin-induced diabetes. Nutrition, Metabolism and Cardiovascular Diseases, 28; (6): 592-9, 2018.

23- MARIA A., MONIKA A., MARA I., OSCAR F., MERCEDES E., et al.: Streptozotocin-Induced Adaptive Modification of Mitochondrial Supercomplexes in Liver of Wistar Rats and the Protective Effect of Moringa oleifera Lam. Biochemistry Research International, 1; 2018: 5681081. doi: 10.1155/2018/5681081. eCollection, 2018.
24- WENJUAN L., WEI G., MIN H., YEMEI L., YEPING Y., et al.: Spironolactone Protects against Diabetic Cardiomyopathy in Streptozotocin-Induced Diabetic Rats. J. Diabetes Res., Oct. 14; 2018: 9232065. doi: 10.1155/ 2018/9232065. eCollection, 2018.

25- ABDEL-SALAM O.M.E., YOUNESS E.R., MOHAMMED N.A., YASSEN N.N., KHADRAWY Y.A., et al.: Novel neuroprotective and hepatoprotective effects of citric acid in acute malathion intoxication. Asian Pacific Journal of Tropical Medicine, 9 (12): 1181-94, 2016.

26- QUAGLIARO L., PICONI L., ASSALONI R., MARTINELLI L., MOTZ E., et al.: Intermittent High Glucose Enhances Apoptosis Related to Oxidative Stress in Human Umbilical Vein Endothelial Cells: The Role of Protein Kinase $\mathrm{C}$ and NAD $(\mathrm{P}) \mathrm{H}-$ Oxidase Activation. Diabetes, 52 (11): 2795-804, 2003.

27- DELVECCHIO F.C., BRIZUELA R.M., KHAN S.R., BYER K., LI Z., et al.: Citrate and vitamin E blunt the shock wave-induced free radical surge in an in vitro cell culture model. Urological Research, 33 (6): 448-52, 2005.

28- ZHANG L., DING W.Y., WANG Z.H., TANG M.X., WANG F., et al.: Early administration of trimetazidine attenuates diabetic cardiomyopathy in rats by alleviating fibrosis, reducing apoptosis and enhancing autophagy. Journal of Translational Medicine, 14 (1): 1-12, 2016.

29- GUO Y., ZHUANG X., HUANG Z., ZOU J., YANG D., et al.: Klotho protects the heart from hyperglycemiainduced injury by inactivating ROS and NF-icB-mediated inflammation both in vitro and in vivo. Biochimica et Biophysica Acta-Molecular Basis of Disease, 1864 (1): 238-51, 2018.

30- OTHMAN A.I., EL-SAWI M.R., EL-MISSIRY M.A. and ABUKHALIL M.H.: Epigallocatechin-3-gallate protects against diabetic cardiomyopathy through modulating the cardiometabolic risk factors, oxidative stress, inflammation, cell death and fibrosis in streptozotocin-nicotinamideinduced diabetic rats. Biomedicine and Pharmacotherapy, 94: 362-73, 2017.

31- YU H., ZHEN J., PANG B., GU J. and WU S.: Ginsenoside $\mathrm{Rg} 1$ ameliorates oxidative stress and myocardial apoptosis in streptozotocin-induced diabetic rats. Journal of Zhejiang University-SCIENCE B, 16 (5): 344-54, 2015.

32- TANG X., LIU J., DONG W., LI P., LI L., et al.: The cardioprotective effects of citric acid and L-malic acid on myocardial ischemia/reperfusion injury. Evid Based Complement Alternat Med., 2013: 820695. doi: 10.1155/ 2013/820695, 2013.

33- TIAN J., LIU Y., LIU Y., CHEN K. and LYU S.: Ginkgo biloba Leaf Extract Protects against Myocardial Injury via Attenuation of Endoplasmic Reticulum Stress in Streptozotocin-Induced Diabetic ApoE ${ }^{-} \Gamma$ Mice. Oxidative Medicine and Cellular Longevity: 25; 2018: 2370617. doi: 10.1155/2018/2370617. eCollection 2018.

34- ZHANG B., SHEN Q., CHEN Y., PAN R., KUANG S., et al.: Myricitrin alleviates oxidative stress-induced inflammation and apoptosis and protects mice against diabetic cardiomyopathy. Sci. Rep., Mar. 13; 7: 44239. doi: 10. 103 8/srep44239, 2017.

35- ABO ELFADL S.G., SHENDI1 M., RASHED L.A. and REDA A.: Comparative Histological Study on the Effect of Stem Cells, and Gene Modified Stem Cells in Experi- 
mentally-Induced Diabetes Type 1 Cardiomyopathy. Journal of Medical Histology, Vol. (1), No (1). DOI: 10.21608/ jmh.2017.1038.1015, 2017.

36- GURUSAMY N.: The potential of Mesenchymal Stem Cells in diabetes mellitus. Diabesity, 3 (1): 1-4, 2017.

37- SHAH S.B., DAVIS J., WEISLEDER N., KOSTAVASSILI I., McCULLOCH A.D., RALSTON E., CAPETANAKI Y. and LIEBER R.L.: "Structural and functional roles of desmin in mouse skeletal muscle during passive deformation". Biophysical Journal, 86 (5): 2993-3008. doi:10.1016/ S0006-3495(04)74349-0, 2004.
38- BÄR H., STRELKOV S.V., SJÖBERG G., AEBI U. and HERRMANN H.: "The biology of desmin filaments: How do mutations affect their structure, assembly, and organisation?". Journal of Structural Biology, 148 (2): 137-52. doi:10.1016/j.jsb.2004.04.003, 2004.

39- SAINI H., TABTABAI S., STONE J.R. and ELLINOR P.T.: Pathophysiology of Cardiomyopathies. In: Cellular and Molecular Pathobiology of Cardiovascular Disease, Willis MS, Jonathon W. Homeister J.W/ and Stone JR. Editors. Academic Press, an imprint of Elsevier, Chapter 6: 101-19, 2014.

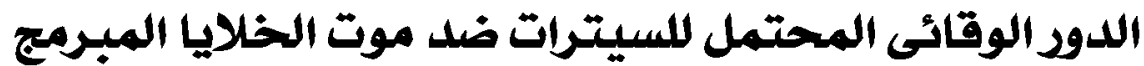

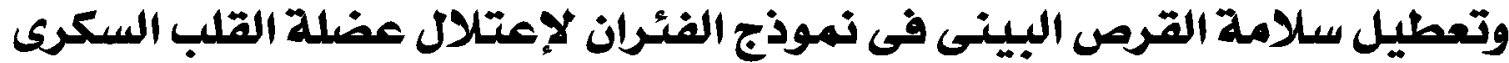

\footnotetext{
المقدمة: قد وصف موت خلايا القلب المبرمج وتعطيل سلامة القرص البينى كتغيرات سلبية لمرض السكرى.

الهدف من العمل: التحقيق في الدور الوقائى المحتمل اللسيترات ضد هذه التغيرات القلية المعاكسة.

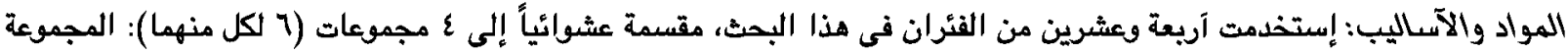

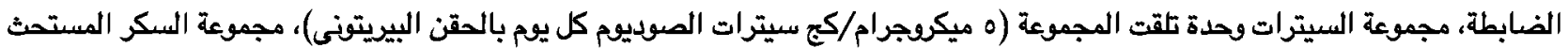

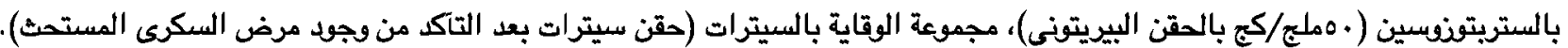

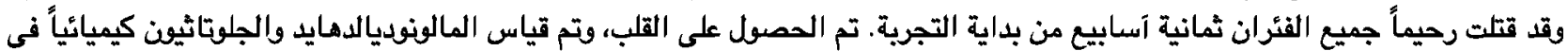

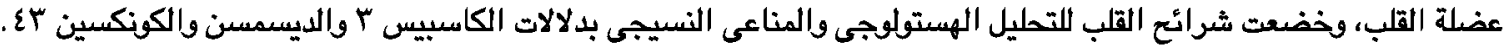

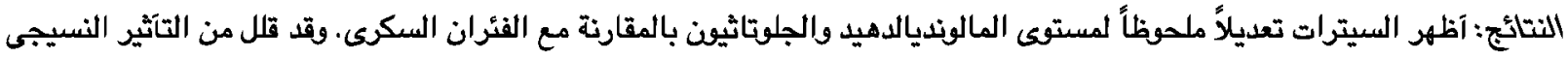

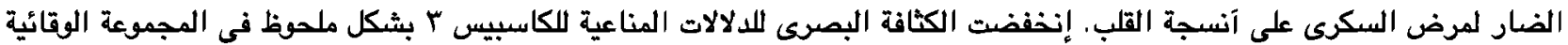

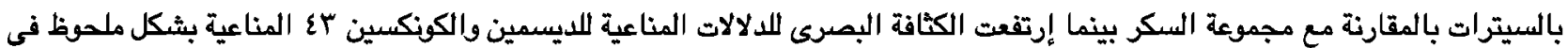
المجموعة الوقائية بالسيترات بالمقارنة مع مجموعة السكرى.

الخلاصة: إن السيترات قد تخفف من موت الخلايا المبرمج القلب فى الفئران السكرى وقد تحافظ على سلامة الآقراص البينية القلية.
} 